УДК $78.03+787.5 / 787.6$

\author{
Наталія Василівна Хмель \\ здобувач кафедри теорії музики та композиції \\ Одеської національної музичної академії імені \\ A. В. Нежданової, викладач кафедри народних $i$ \\ нструментів Дніпропетровської академії \\ музики імені М. Глінки \\ tusyaband@gmail.com
}

\title{
СПЕЦИФІКА ТРАНСФОРМАЦІЇ ІНСТРУМЕНТАЛЬНОЇ МУЗИКИ БАРОКО ДЛЯ БАНДУРИ НА ПРИКЛАДІ «СОНАТИ G-MОLL ДЛЯ ВІОЛОНЧЕЛІ ТА ФОРТЕПІАНО (PIANOFORTE)» (ЗА IHCTPУМЕНТАЛЬНИМ КОНЦЕРТОМ) Г. Ф. ГЕНДЕЛЯ
}

\begin{abstract}
Мета дослідження - виявлення особливостей перекладення творів епохи бароко та їх практична апробація при інтерпретації на бандурі. Методологія дослідження полягає у застосуванні компаративного, історичного, структурно-функціонального методів, які забезпечують цілісне сприйняття особливостей музичної мови музики минулих століть, а також методології системного аналізу для всебічного врахування умов трансформації музики бароко в поєднанні з узагальненням як методом формулювання висновків. Здійснено музично-виконавський аналіз образного змісту, композиційних і стильових особливостей сонати. Наукова новизна полягає у розширенні методів перекладення та обтрунтуванні основних засобів трансформації музики епохи бароко для бандури, на прикладі перекладення інструментальних творів Г. Ф. Генделя. Висновки. На основі музично-виконавського аналізу «Сонати g-тоll для віолончелі та фортепіано (pianoforte)» (за інструментальним концертом) Г. Ф. Генделя в перекладенні для бандури та фортепіано С. В. Овчарової (у чотирьох частинах), а також особливостей трансформації партії віолончелі для бандури можна зробити висновок, що перекладення творів епохи бароко для бандури містить певний потенціал для реалізації. Це доводять багатогранна звукова темброколористика та фактурні можливості сучасного модифікованого інструменту - бандури, шо підтверджує процес його академізації та значно збагачує як навчальний, так і концертний репертуар представників бандурного мистецтва.
\end{abstract}

Ключові слова: темброво-фактурні особливості, трансформація, перекладення, епоха бароко, інтерпретація, сонатний жанр, структура.

Khmel Natalya, degree-seeking of department of music theory and composition of Odessa National music academy named A. V. Nezhdanova, teacher

(C) Хмель Н. В., 2017 
of department of Folk instruments of Dnipropetrovsk academy of music named M. Glinka

The speciffics of the transformation of instrumental music of the baroque for bandura on the example of «Sonata g-moll for cello and piano (pianoforte)» (on the instrumental concert) of G.F. Hendel

The purpose of the research is to identify the peculiarities of the transformation of the works of the Baroque epoch and their practical evaluation at the interpretation for bandura. The methodology of the research is to apply comparative, historical, structural and functional methods that provide a coherent perception of the peculiarities of the musical language of music of the last century, as well as the methodology of the system analysis for the comprehensive consideration of the conditions for the transformation of Baroque music, in conjunction with the generalization as a method for the formulation of the conclusions. A musical-performing analysis of the figurative content, compositional and stylistic features of sonatas was performed. The scientific novelty is to expand the methods of translation and substantiation of the basic means of transforming music of the Baroque epoch for bandura, on the example of the instrumental works by G. F. Hendel. Conclusions. On the basis of the musical-performing analysis of «Sonata g-moll for cello and piano (Pianoforte)» (by an instrumental concert) of $G$. F. Hendel arranged for bandura and piano by $S$. V. Ovcharova (in four parts), as well as features of transformation of the part of the cello for bandura, we can make a conclusion that an arrangement of works of the Baroque epoch for bandura has a certain potential for realization. This is proved by the multifaceted timbre-coloring and texture possibilities of the modern modified instrument - bandura, which confirms the process of its academicization and greatly enriches both the educational and concert repertoire of the representatives of bandura art.

Keywords: timbre and texture peculiarities, transformation, arrangement, the Baroque epoch, interpretation, sonata genre, structure.

Хмель Наталия Васильевна, соискатель кафедры теории музыки и композиции Одесской национальной музыкальной академии имени A. В. Неждановой, преподаватель кафедры народных инструментов Днепропетровской академии музыки имени М. Глинки

Специфика трансформации инструментальной музыки барокко для бандуры на примере «Сонаты g-moll для виолончели и фортепиано (pianoforte)» (по инструментальному концерту) Г. Ф. Генделя

Цель исследования - выявление особенностей переложения произведений эпохи барокко и их практическая апробация при интерпретации на бандуре. Методология исследования заключается в применении компаративного, исторического, структурно-функционального методов, обеспечивающих целостное восприятие особенностей музыкального языка музыки прошлых веков, а также метода системного анализа для все- 
стороннего учета условий трансформации музыки барокко в сочетании с обобщением, как методом формулирования выводов. Сделан музыкальноисполнительский анализ образного содержания, композиционных и стилевых особенностей сонаты. Научная новизна заключается в расширении методов переложения и обосновании основных средств трансформации музыки эпохи барокко для бандуры, на примере переложения инструментальных произведений Г. Ф. Генделя. Выводы. На основе музыкально-исполнительского анализа "Сонаты g-тоll для виолончели и фортепиано (pianoforte)» (по инструментальному концерту) Г. Ф. Генделя в переложении для бандуры и фортепиано С. Овчаровой (в четырех частях), а также особенностей трансформации партии виолончели для бандуры можно сделать вывод, что переложение произведений эпохи барокко для бандуры содержит определенный потенциал для реализации. Это доказывает многогранная звуковая темброколористика и фактурные возможности современного модифицированного инструмента - бандуры, что подтверждает процесс его академизации и значительно обогащает как учебный, так и концертный репертуар представителей бандурного искусства.

Ключевые слова: темброво-фактурные особенности, трансформация, переложение, эпоха барокко, интерпретация, сонатный жанр, структура.

Постановка проблеми. Складний та довготривалий процес становлення професіональної школи бандурного мистецтва призвів до започаткування у 50-х роках XX сторіччя мережі професійних навчальних закладів у різних регіонах України, що відрізнялися власними методиками гри, типами інструментів та репертуаром. Отримання професійної бандурної освіти відновлюється з відкриттям у 1945 році класу бандури в музичному училищі імені Р. Глієра, а згодом в Киїській державній консерваторії ім. П. І. Чайковського. Популяризацію та розвиток бандурного мистецтва Київського регіону очолив В. А. Кабачок, традиції якого продовжили професор С. В. Баштан та багато інших видатних представників академічної бандурної школи. На Галичині поштовхом до популяризації та професійного розвитку гри на бандурі стає у 1950 році відкриття класів бандури в першій і другій музичних школах та музичному училищі Львова. Згодом професійну бандурну школу західного регіону очолив В. Я. Герасименко - майстер (конструктор бандури-«львів’янки»), бандурист та педагог, у майбутньому професор Львівської державної консерваторії ім. М. Лисенка [5, 10-11]. 31944 року клас бандури стає окремою спеціалізацією і в Дніпропетровському музичному училищі імені М. Глінки, до того вивчення інструменту було в якості ознайомлення. 
Вагомий внесок у розвиток та популяризацію бандурного виконавства та освіти зробила випускниця Дніпропетровського музичного училища імені М. Глінки та Київської державної консерваторії ім. П. І. Чайковського Л. Воріна, яка за роки своєї творчої праці виховала плеяду високопрофесійних представників Дніпропетровської академічної бандурної школи (1956-2006) [12, 10]. У 1968 році в історії бандурного виконавства відбулася значна подія. На прилюдному захисті дисертаційного дослідження А. Омельченка було представлено нову модифіковану конструкцію інструменту, для створення якого плідно працювали В. Тузиченко, В. Герасименко, I. Скляр, С. Баштан, А. Омельченко та П. Іванов. Було винайдено хроматичну бандуру з механічним переключенням тональностей [10, 102-103].

Активне введення бандури у сучасний виконавський простір породжує новітні завдання та певні протиріччя, що потребує методологічного вирішення. 3 одного боку, бандура як самобутній народний інструмент прагне зберегти свою автентичність, з іншого - розширення бандурного репертуару відбувається не тільки за рахунок модифікації етнічних творів суто бандурного призначення. Активізація процесів введення в концертний репертуар бандури творів інструментального академічного мистецтва підсилює значущість цього інструменту для сучасного академічного простору.

Означимо основні тенденції, що актуалізуються в музичному мистецтві сьогодення:

- збільшується загальна потреба в репертуарі для окремих інструментів та різних складів ансамблів та оркестрів;

- зростає зацікавленість слухача до різновидів тембрових та змістовних інтерпретацій музичних творів минулого відповідно до сучасного оновлення концертного репертуару;

- підсилюється тенденція щодо розширення бандурного репертуару за рахунок перекладень, транскрипцій творів відомих композиторів європейської та вітчизняної академічної музики;

- активізується інтерес до національної музичної культури та мистецтва, відповідно до переосмислення ролі та значення українського етносу та його місця в загальноєвропейській культурі.

Аналіз останніх досліджень і публікацій. Проблема перекладення та виконання творів різних жанрів для народних інструментів і використання їх у навчально-виховному процесі були темою дослідження багатьох вітчизняних науковців, а саме I. Дмитрук «Жанр перекладу та його різновиди в сучасному бандурному мистецтві» [4]; В. Дутчак 
«Розвиток професійних засад бандурного мистецтва 1970-1990 років» [6]; С. Карася «Інтерпретація музики бароко на баяні (теоретико-виконавський аспект)» [7]; В. Дейнеги «Перекладення як процес переосмислення засобів оркестрової виразності» [3]; I. Теуту «Транскрипція в українському цимбальному мистецтві: історичний та теоретичний аспекти» [11] тощо. Утім представлені дослідження науковців із зазначеної проблематики недостатньо висвітлили сучасні аспекти трансформації бандурного репертуару, що спонукає до подальшого наукового осмислення.

Актуальність дослідження обумовлена сучасними процесами інтеграції виконавського репертуару минулого в широкий простір концертної культури сучасності. Обгрунтування основних принципів трансформації музичних шедеврів епохи бароко для бандури, яка є історичним символом народу та посідає одне з голових місць в формуванні специфіки та неповторності змістовних та стильових особливостей українського музичного мистецтва, відповідає нагальним потребам переосмислення шляхів репертуарного осучаснення.

Мета дослідження - виявлення особливостей перекладення творів епохи бароко та їх практична апробація при інтерпретації на бандурі.

Методологія дослідження полягає у застосуванні компаративного, історичного, структурно-функціонального методів, які забезпечують цілісне сприйняття особливостей музичної мови музики минулих століть, а також методології системного аналізу для всебічного врахування умов трансформації музики бароко в поєднанні з узагальненням як методом формулювання висновків. Здійснено музичновиконавський аналіз образного змісту, композиційних і стильових особливостей сонати.

Наукова новизна полягає у розширенні методів перекладення та обгрунтуванні основних засобів трансформації музики епохи бароко для бандури, на прикладі перекладення інструментальних творів Г. Ф. Генделя.

Виклад основного матеріалу дослідження. Сонатний жанр в епоху бароко займав провідне місце в інструментальній музиці різних європейських народів. Особливо значущу роль він відіграє в творчості Георга Фрідріха Генделя.

Гендель посідає одне із визначальних місць в становленні цього жанру. «Ідейно-художній зміст, драматургія, структура циклу, своєрідність поєднання гомофонно-гармонійного і поліфонічного принципів розвитку, елементи композиції, що передбачають класичне 
сонатне allegro сконцентрували в сонатах особливості найважливішого стильового напрямку інструментальної музики епохи бароко і рельєфно виявили новаторські риси стилю Генделя в еволюції жанру» $[2,2,4]$.

У чотирьохчастинній структурі сонати викристалізовується розподіл частин на пари. Якщо в першій парі центром є друга частина, то в другій - це повільна частина, яку слід розглядати і як психологічну кульмінацію всього циклу: Grave (29 т.); Allegro (48 т.); Sarabande. Largo (42 т.); Allegro (70 т.). Концепція sonata da chiesa базується на послідовному розгортанні вкрай протилежних сфер: від піднесеної патетики, «мовної» декламаційності (перша частина) до динамічної енергії дії (друга), далі - суб'єктивно забарвленої лірики (третя) і, нарешті - стрімкого фіналу [2, 8].

Перша частина - GRAVE - відкривається п'ятитактовим фортепіанним вступом, що налаштовує слухача на рішучий, серйозний, урочисто-скорботний характер. Тема виходить з вершини інтонаційного джерела і далі секвенційно поступово рухається в низхідному напрямку до тонічного акорду першої октави. Всупереч низхідному руху динаміка зростає, досягаючи в останніх тактах вступу максимальної звучності - ff. Основна тема, яка звучить у солюючого інструменту, характеризується переважно поступовим мелодійним рухом (виключаючи єдину квартову рішучу інтонацію, підкреслену пунктирним ритмом). Подальший розвиток матеріалу призводить до відхилення в паралельний мажор - B-dur, однак ритмічний характер руху зберігається. Будова фраз - потактова, рясніє рухомою динамікою (crescendo / diminuendo).

Перша частина сонати - безумовний шедевр глибини і логічної потужності мислення Генделя. Разом з тим інтонації цієї частини такі виразні, такі опуклі, що, здається, приховують за собою слова, служать пластичними музичними формами душевних рухів.

Друга частина - ALLEGRO. В частині Allegro при деякій схожості основ дано, однак, інше рішення, складається інший образ. Якщо в першій частині була віддача себе під владу мірного бігу, швидко мінливих вражень, то тут сам рух підпорядковується небачено концентрованій емоції, насичується переживанням. Сила, блиск, пафос, густота звучання - ось основні відмінності даного розділу. Стрімкий рух шістнадцятими поперемінно в партії соліста і супроводу, переважно яскрава динаміка, різні штрихові та артикуляційні рішення, хвилеподібна мелодійна лінія, різкі контрасти регістрів - всі ці засо- 
би виразності покликані відобразити напористий, рішучий та блискавичний характер розділу.

Tретя частина - SARABANDE. LARGO написана в тональності B-dur. Основну тему характеризує плавний поступовий рух в характерному тридольному метрі (зустрічаються мелодійні стрибки, які завжди звучать із заповненням), комплементарна ритміка, переважна помірна динаміка, що створює ніжне звукове плетіння. Сарабанда в соль-мінорній сонаті Генделя є осередком ліричних емоцій, «ліричним центром». Зосередженість почуття, патетика, що таїться в його глибинах, розкриваються тут з великою стриманістю, в виразах лаконічних і строгих. Простота гомофонного викладу, діатонічність мелодії, майже звільненої від властивої жанру мелізматики, розміреність і періодичність структури, де кожна побудова відокремлена від іншої повною досконалою каденцією, що збирає всі голоси в один довгий акорд, - все це викликає асоціації з творами хорального складу. Сарабанда як лірична кульмінація нібито підводить рису попередньому розвитку, межу, за якою настає різке збільшення контрастності.

Четверта частина - ALLEGRO зберігає тридольність руху, проте звучить вже в зовсім іншому характері. Метро-ритмічне рішення фіналу, швидкий темп - все це наближає розділ до жиги - барочного танцю, що традиційно замикає цикл сюїти. Однаковість ритміки і моторність руху створюють враження невпинного звукового потоку. Стрімкий, динамічний фінал.

Даний твір в оригіналі написано для віолончелі та клавіру (pianoforte). Також можна почути інтерпретацію його на духових інструментах, зокрема тромбоні, оскільки і віолончельна партія і партія тромбону нотуються в теноровому ключі. Ми ж спробували виконати сонату на бандурі, перекладення якої здійснила С. В. Овчарова.

Дуже важливим фактором є розуміння триєдності зв'язку між композитором - виконавцем - слухачем, де сполучну роль в даному зв'язку відіграє перекладач, а саме його професійна та грамотна робота в процесі переробки музичного матеріалу минулого для інтерпретації в сучасному просторі.

Одним з головних принципів темброво-фактурної трансформації $\epsilon$ максимальне проникнення в образну сферу оригіналу та втілення характеру твору вже в новій, сучасній інтерпретації. Звернемо увагу, що тональність сонати не потребує транспозиції, оскільки вона входить в коло зручних тональностей на бандурі, та діапазон твору не виходить за межі бандурного. 
Зосередимо увагу на деяких важливих аспектах перекладення та специфіці інтерпретації представленої сонати на бандурі:

- до основних принципів перекладення скрипкової або віолончельної музики належить метод ампліфікації (згущення фактурного викладу) при роботі з оригіналом, оскільки бандурне звучання менш насичене, ніж звучання скрипки або віолончелі. Укріплення партії бандури гармонічно - терціями, октавами, октавами з терцією, акордами, в повільних частинах переважно кварто-квінтовими акордами, де терцовий звук залишається в басовій партії (таке гармонічне поєднання характерне для музики епохи бароко) тощо. Дане збагачення фактурного викладу сприяє більш насиченому, наповненому та глибокому відтворенню музичної тканини твору, що в певній мірі компенсує недостатність сили звучання акомпанементу бандури та дозволяє «частково» відповідати величі та багатогранності фортепіанного супроводу. Розглядаючи викладення оригіналу переважно дрібними тривалостями (восьмими та шістнадцятими), музична тканина майже не потребує гармонічного згущення фактури та залишається одноголосною (перша частина - Grave, 10 т.);

- приєднуючись до італійської практики та частково англійської школи, Гендель в своєму мистецтві застосовував досить легкий вид орнаментики, яка в більшості випадків обмежувалася форшлагами, трелями, мордентами, аподжатурами, висхідними арпеджіато та групето $[1,98]$. В даному творі із вищевизначених типів прикрас зустрічається лише трель. При адаптації першої частини сонати для інтерпретації на бандурі перекладач навіть вводить трель самостійно для створення педальності звучання окремих нот більш довгих тривалостей (перша частина - Grave, 6 т.);

- для насичення фактурного викладення перекладач додає в партію бандури октави на четверту долю, спираючись на партію фортепіанного супроводу, шо утворює ефект безперервності та протяжності звучання (перша частина - Grave, 7, 8 тт.);

- одним з характерних недоліків струнно-щипкових інструментів $€$ відсутність демпферного механізму, що призводить до нашарування одного звуку на інший, через це виконавець під час інтерпретування повільних частин твору обов'язково повинен прикривати вже зіграні акорди, інтервали, або окремі ноти перед взяттям наступних, якщо їх тривалість звучання більша ніж чверть;

- при трансформації партія лівої руки виписується за методом редукції (якщо басова лінія в оригіналі нотується в малій октаві, бан- 
дуристи найчастіше переносять ії̈ у велику, для більш ясного, чіткого прослуховування та зручного виконання);

- в швидких частинах автор перекладення зазвичай спрощує фактурне викладення, або залишає його незмінним, щоб зберегти віртуозність, граціозність, легкість звучання, темп та головне - характер твору;

- особливу увагу треба звернути на артикуляцію. Ми будемо спиратись на загальновідомі особливості відтворення штрихів музики бароко. Чергування штрихів legato, non legato, та staccato допомагає максимально урізноманітнити образну сферу твору. Відмінною рисою стилю майстрів епохи бароко $є$ контраст в артикулюванні сусідніх тривалостей: дрібні тривалості граються legato, а більші - non legato чи staccato. Зазначимо, що інтерпретування штрихів на бандурі має дещо умовний характер у порівнянні з інструментами, що належать до родини клавішних або струнно-смичкових. При відтворенні штриху staccato на бандурі виконавець повинен користуватися гострим, невисоким, уривчастим щипком та особливу увагу звертати на звільнення струни, яке має відповідати характеру музики. При інтерпретації штриху legato, бандурист переважно використовує глибокі рухи, з пучки на ніготь. Протяжність звучання музичних ліній, викладених довгими тривалостями, зазвичай компенсується продовженням руху кисті руки та внутрішнім доспівуванням, що безумовно відображується на характері звучання. Музична фактура твору, викладена більш дрібними тривалостями (шістнадцятими), потребує виставлення зручної аплікатури для використання підготовлених рухів;

- торкаючись особливостей динаміки, зазначимо, що найвищий свій розквіт принцип динаміки forte і piano отримав саме в епоху бароко та виявився в мистецтві «добре організованого контрасту» та тяжінні до монументальних поліфонічних форм вокальної та інструментальної музики, до яскравих ефектів світлотіні. Типовою для даної епохи була контрастна динаміка та більш тонкий ії прояв - динаміка регістрів. Але в той же час набували популярності й плавні, поступові зміни гучності звучання, чому сприяв корінний переворот у сфері музичного інструментарію (кінець XVII - початок XVIII сторіччя). Звернемо увагу, що композитори епохи бароко розглядали виконавців як співавторів та більшість засобів музичної виразності залишали на їх власний смак та розсуд: темп, динаміку, розшифрування прикрас та цифрованого басу, нерідко навіть визначення інструментального складу. «При розгляді даного питання слід враховувати, що 
в старовинній музиці динаміка відігравала особливу роль, служила найважливішим дієвим фактором, що сприяв прояву кінетичної енергії, яка міститься в музиці» $[9,43]$. Вивчаючи саме Генделевський стиль та особливості динамізації, зазначимо, що композитор зазвичай не використовував динамічні вказівки у клавірних творах, проте в оркестровій музиці їх чимало: pianissimo, piano, mezzo piano, mezzo forte, un poco piu, un poco forte, forte, fortissimo. Лише відсутні вказівки поступової зміни гучності - crescendo та diminuendo. «Численні італійські впливи, як і різноманітність інтонаційного змісту творів Генделя, показують, що його музика не завжди залишається в суворих рамках бароко, а схилялася іноді й до галантного стилю» $[8,159]$. В представленій сонаті сучасні виконавці користуються контрастним і хвилеподібним типами динамічного регістрування.

Висновки. На основі вищенаведеного музично-виконавського аналізу «Сонати g-moll для віолончелі та фортепіано (pianoforte)» (за інструментальним концертом) Г. Ф. Генделя в перекладенні для бандури та фортепіано С. В. Овчарової (у чотирьох частинах), а також особливостей трансформації партії віолончелі для бандури можна зробити висновок, що перекладення творів епохи бароко для бандури містить певний потенціал для реалізації. Це доводить багатогранна звукова темброколористика та фактурні можливості сучасного модифікованого інструменту - бандури, що підтверджує процес його академізації та значно збагачує як навчальний, так і концертний репертуар представників бандурного мистецтва.

3 погляду на те, що процес модернізації та академізації бандури ще триває, проблема збагачення їі репертуару набуває особливого значення та $є$ актуальною у сучасному виконавському мистецтві. Перекладення інструментальних творів епохи бароко, зокрема Г. Ф. Генделя, допомагає вирішити дане питання, урізноманітнюючи та поповнюючи виконавський простір народно-академічного мистецтва.

Примітки:

Овчарова Світлана Валентинівна - професор кафедри «Народні інструменти» Дніпропетровської академії музики ім. М. Глінки, заслужений працівник культури України, керівник капели бандуристів «Чарівниці», директор-розпорядник міжрегіонального фестивалюконкурсу ансамблів бандуристів «Дзвени, бандуро!». Багато зробила для розширення репертуару для ансамблів бандуристів та бандури соло, створила оригінальні обробки, перекладення, аранжування українських народних пісень, творів вітчизняної та зарубіжної вокаль- 
ної та інструментальної духовної та сучасної музики. Створила програми «Спеціальний клас бандури» та «Постава голосу. Клас бандури». Обидві для вищих навчальних закладів культури і мистецтв I-II рівнів акредитації (2007). Автор робочих програм та методичних рекомендацій до навчальних дисциплін «Фах» та «Капела бандуристів» (освітній ступінь «бакалавр», «магістр» 2016 р.). Є автором наукових статей, п’яти навчальних та шести навчально-методичних посібників.

\section{СПИСОК ЛІТЕРАТУРИ}

1. Бейшлаг А. Орнаментика в музыке. Москва: Музыка, 1978. 320 с.

2. Булатов Л. Скрипичные сонаты Г. Ф. Генделя: автореф. дис. ... канд. искусствоведения: 17.00.02 / Госуд. конс. им. Н. А. Римского-Корсакова. Ленинград, 1990. 12 с.

3. Дейнега В. Перекладення як процес переосмислення засобів оркестрової виразності: автореф. дис. ... канд. мистецтвознавства: 17.00.03 / Одес. держ. муз. акад. ім. Антоніни Нежданової. Одеса, 2006. 19 с.

4. Дмитрук I. Жанр перекладу та його різновиди в сучасному бандурному мистецтві: автореф. дис. ... канд. мистецтвознавства: 17.00.03 / Львів. нац. муз. акад. ім. Миколи Лисенка. Львів, 2009. 18 с.

5. Дубас О. Становлення та розвиток кобзарських шкіл в Україні (XVIIперша половина XX століття): автореф. дис. ... канд. мистецтвознавства: 17.00.03 / Інститут мистецтвознавства, фольклористики та етнології ім. Максима Рильського. Київ, 2002. 13 с.

6. Дутчак В. Розвиток професійних засад бандурного мистецтва 19701990 років. Творчість і виконавство: автореф. дис. ... канд. мистецтвознавства: 17.00.03 / Нац. муз. акад. України ім. Петра Чайковського. Київ, 1996. 25 с.

7. Карась С. Інтерпретація музики бароко на баяні (теоретико-виконавський аспект): автореф. дис. ... канд. мистецтвознавства: 17.00 .03 / Львів. держ. муз. акад. ім. Миколи Лисенка. Львів, 2006. 20 с.

8. Кашкадамова Н. Мистецтво виконання музики на клавішно-струнних інструментах: навч. посіб. Тернопіль: СМП «Астон», 1998. 300 с. нот.

9. Копчевский Н. Клавирная музыка. Вопросы исполнения. Москва: Музыка, 1986. 96 с. нот.

10. Полтавець Л. Тема дисертації - кобзарське мистецтво. Народна творчість та етнографія. 1968. № 5. С. 102-103.

11. Теуту I. Транскрипція в українському цимбальному мистецтві: історичний та теоретичний аспекти: автореф. дис. ... канд. мист-ва: 17.00.03 / Інстит. мистецтвознавства, фольклорістики та етнології ім. Максима Рильського. Київ, 2016. 19 с.

12. Чернета Т. Наслідування автентичних кобзарських традицій у сучасній музичній практиці. Мистецтвознавчі записки: зб. наук. праць. Київ, 2009. Вип. 15. С. 58-63. 


\section{REFERENCES}

1. Beyshlag, A. (1978). Ornamentatics in music. Moskva: Muzyka [in Ukrainian].

2. Bulatov, L. (1990). G. F. Handel's violin sonatas: Extended abstract of candidate's thesis. Leningrad: Gosud. kons-iya im. Nikolaya Andreevicha Rimskogo-Korsakova [in Russian].

3. Deynega, V. (2006). Arrangement as a process of rethinking of orchestral expression means. Extended abstract of candidate's thesis. Odesa: Odes. derzh. muz. akad. im. Antoniny Nezhdanovoji [in Ukrainian].

4. Dmitruk, I. (2009). Genre of transposition and its variants in modern bandura art. Extended abstract of candidate's thesis. Ljviv: Ljviv. nac. muz. akad. im. Mykoly Lysenko [in Ukrainian].

5. Dubas, O. (2002). Formation and development of kobzar schools in Ukraine (XVII - first half of XX century). Extended abstract of candidate's thesis. Kyiv: Instytut mystectvoznavstva, foljklorystyky ta etnologhiji im. Maksyma Ryljsjkogho [in Ukrainian].

6. Dutchak, V. (1996). Development of the professional bases of bandura art of 1970-1990. Creativity and performance. Extended abstract of candidate's thesis. Kyiv: Nac. muz. akad. Ukrajiny im. Petra Chajkovsjkogho [in Ukrainian].

7. Karasj, S. (2006). Interpretation of baroque music on bayan (theoretical-performing aspect). Extended abstract of candidate's thesis. Lviv: Ljviv. derzh. muz. akad. im. Mykoly Lysenka [in Ukrainian].

8. Kashkadamova, N. (1998). The art of performing music on keyboards. Ternopil: SMP «ASTON» [in Ukrainian].

9. Kopchevskyj, N. (1986). Clavier music. Issues of performance. Moscow: Muzyka [in Russian].

10. Poltavecj, L (1968). The theme of the dissertation is kobzar art. Narodna tvorchistj ta etnoghrafija, 5, 102-103 [in Ukrainian].

11. Teutu, I. (2016). Transcription in the Ukrainian cymbal art: historical and theoretical aspects: Extended abstract of candidate's thesis. Kyiv: Instyt. mys-va, foljklor. ta etnol. im. Maksyma Ryljsjkogho [in Ukrainian].

12. Cherneta, T (2009). The imitation of authentic kobzar traditions in modern musical practice. Mystectvoznavchi zapysky: zb. nauk. pracj, 15, 58-63 [in Ukrainian].

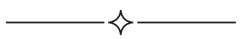

